\title{
Enzyme-linked immunosorbent assay for the detection of serum antibody to outer membrane proteins of Treponema pallidum
}

\author{
J MORRISON-PLUMMER, J F ALDERETE, AND J B BASEMAN \\ From the Department of Microbiology, University of Texas Health Science Center, San Antonio, Texas, \\ USA
}

SUMMARY A highly sensitive enzyme-linked immunosorbent assay was used for the analysis of serum IgG reactivity against specific immunogenic Treponema pallidum proteins. Outer membrane treponemal proteins purified by preparative SDS-polyacrylamide gel electrophoresis were used as antigenic probes at concentrations as low as $100 \mathrm{ng}$ per $\mathrm{ml}(5 \mathrm{ng}$ per well in microtitre plates). Detection of anti-treponemal antibody was possible using rabbit syphilitic sera diluted to $1 / 10000$. The sensitivity of the assay was equal to or greater than that detected by radioimmunoprecipitation combined with gel electrophoresis and fluorography techniques and was capable of monitoring host IgG responses throughout the progress of the disease.

\section{Introduction}

Immunological characterisation of the host response to Treponema pallidum infection has identified several outer membrane treponemal proteins as major immunogens. ${ }^{1-4}$ Serum IgG antibodies against these $T$ pallidum antigens in patients with syphilis and in experimentally infected rabbits have been detected by radioimmunoprecipitation combined with sodium dodecylsulphate-polyacrylamide gel electrophoresis and autoradiography-fluorography techniques. ${ }^{3}$ These data indicated a predictable pattern for early and prolonged host humoral response to specific $T$ pallidum polypeptides.

We report a simple, rapid, and highly sensitive microassay which circumvented standard radioimmunoassays, crossed-immunoelectrophoresis procedures, and other classical antigenicallyundefined serological tests. ${ }^{5-9}$

\section{Materials and methods}

TREPONEMA PALLIDUM ORGANISMS

Treponema pallidum (Nichols strain) organisms were passaged in testes of New Zealand white male rabbits

Address for reprints: Dr J B Baseman, Department of Microbiology, University of Texas Health Science Center, 7703 Floyd Curl Drive, San Antonio, Texas 78284, USA

Accepted for publication 22 September 1982
(3-3.5 kg). The rabbits were maintained at $16-18^{\circ} \mathrm{C}$ in isolation cubicles before and during treponemal infection. Isolated treponemes were preserved in $10 \%$ dimethyl sulphoxide in liquid nitrogen before intratesticular inoculation of the rabbits. ${ }^{10}$ Treponemes were extracted and purified according to procedures described..$^{1-2}$

\section{RADIOIMMUNOPRECIPITATION ASSAY} These assays were performed as described. ${ }^{3}$

T PALLIDUM PROTEINS FROM ACRYLAMIDE GELS Specific treponemal proteins previously labelled protein 1 (P1; 89500 daltons), P2 (29.5 K), P3 $(25 \cdot 5 \mathrm{~K}), \mathrm{P} 4(20 \mathrm{~K}), \mathrm{P} 5(59 \mathrm{~K})$, and P6 (42.5 K) were purified by preparative electrophoresis on sodium dodecylsulphate (SDS)-polyacrylamide $(7 \cdot 5 \%)$ (PAGE) slab gels as described for $T$ pallidum. ${ }^{1}$ The location of appropriate protein bands was determined by Coomassie brilliant blue (Sigma Chemical Co, St Louis, MO, USA) staining of a small longitudinal section of the gel and then by direct correlation between these profiles and matched gel patterns of $\left[{ }^{35} \mathrm{~S}\right]$ methionine intrinsically-labelled $T$ pallidum proteins. Corresponding unstained protein bands in the preparative gels were sliced, macerated, and gently shaken in $\mathrm{H}_{2} \mathrm{O}$ for $48-60$ hours at $4^{\circ} \mathrm{C} .{ }^{11}$ Except for $\mathrm{P} 1$, the remaining protein bands were mixed in combinations of P2P3 and P4P5P6. 


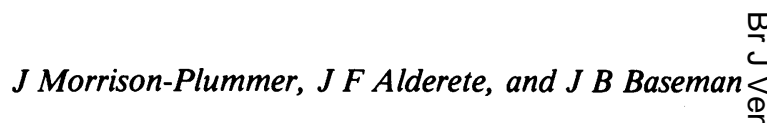

The eluted protein suspension was centrifuged at $17000 \times g$ for 20 minutes to pellet acrylamide fragments. Supernatants -were lyophilised and reconstituted in 1-2 $\mathrm{ml} \mathrm{H}_{2} \mathrm{O}$. The eluted preparations were re-examined by SDS-PAGE using $7 \cdot 5 \%$ acrylamide slab gels to establish their purity. Protein concentrations were estimated by the Bradford technique $^{12}$ and by comparison of the intensity of stained bands of purified protein to standard bovine serum albumin (BSA; Sigma).

ANTIGEN ATTACHMENT TO POLYVINYL-

CHLORIDE MICROTITRE PLATES

Freshly extracted $T$ pallidum organisms were purified by Methocel (Dow Chemical Co, Midland, MI)-Hypaque (Winthrop Laboratories, New York) gradient centrifugation as described. ${ }^{1}$ Treponemal suspensions containing approximately $3 \times 10^{8}$ organisms per $\mathrm{ml}$ were washed once using phosphatebuffered saline (PBS; $137 \mathrm{mmol} / \mathrm{l} \mathrm{NaCl}, 2.7 \mathrm{mmol} / \mathrm{l}$ $\mathrm{KCl}, 4.6 \mathrm{mmol} / 1 \mathrm{Na}_{2} \mathrm{HPO}_{4}$, and $1.5 \mathrm{mmol} / \mathrm{l}$ $\mathrm{KH}_{2} \mathrm{PO}_{4}, \mathrm{pH} \mathrm{7 \cdot 2)}$ and centrifuged for 10 minutes at $17500 \times \mathrm{g}$. Pellets were resuspended to $3.5 \times 10^{7}$ treponemes per ml PBS. ${ }^{1314}$ Fifty microlitres were distributed into each well of 96-well PVC microtitre plates (Dynatech Laboratories, Alexandria, VA, USA), and suspensions dried in air at $37^{\circ} \mathrm{C}$. Then $50 \mu$ of $95 \%$ ethanol were added to each well, and plates were dried at $37^{\circ} \mathrm{C}$ and stored under desiccant at $4^{\circ} \mathrm{C}$ until used.

Purified $T$ pallidum proteins were diluted to $1 \mu \mathrm{g} / \mu \mathrm{l}$ in carbonate buffer, ${ }^{15}$ aliquoted ( $50 \mathrm{ng} /$ well) on to 96-well microtitre plates, and incubated overnight at $4^{\circ} \mathrm{C}$. If not used immediately, plates were washed once with PBS, filled with PBS-1\% BSA and stored at $-20^{\circ} \mathrm{C}$.

ENZYME-LINKED IMMUNOSORBENT ASSAY (ELISA)

A modified ELISA technique ${ }^{15}$ was used for detecting antibodies to both whole $T$ pallidum organisms and extracted treponemal proteins. Briefly, after antigen coating of PVC microtitre plates wells filled with PBS supplemented with 1\% BSA were incubated for a minimum of two hours at $37^{\circ} \mathrm{C}$. Plates were then washed three times with PBS, and $50 \mu$ of test serum diluted with PBS-1\% BSA were added to the designated wells. After incubation for one hour at $37^{\circ} \mathrm{C}$ the plates were washed four times with PBS. Fifty-microlitre aliquots of alkaline phosphatase conjugated goat anti-rabbit IgG (Miles Laboratories, Elkhart, IN, USA) diluted 1/3000 in PBS-1\% BSA were then added to each well. Plates were incubated for one hour at $37^{\circ} \mathrm{C}$ followed by sequential washing with PBS (three times) and distilled $\mathrm{H}_{2} \mathrm{O}$ (twice). Finally, $50 \mu \mathrm{l}$ of $1 \mathrm{mg} / \mathrm{ml}$

disodium p-nitrophenyl phosphate (Sigma) prepared $\stackrel{\widehat{\Phi}}{-}$ in diethanolamine buffer ${ }^{15}$ were added to each well, $\underline{ }$.

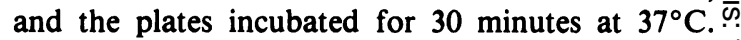
Antibody reactivity was measured by optical density $\overrightarrow{\vec{F}}$ readings at $405 \mathrm{~nm}$ using a MicroElisa Reader(Dynatech).

\section{SERA}

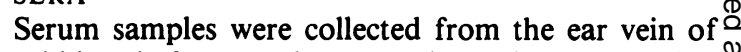
rabbits before and at various intervals after $\tilde{D}$ infection. ${ }^{3}$ All sera were stored at $-70^{\circ} \mathrm{C}$ before use. $\vec{\circ}$

\section{Results}

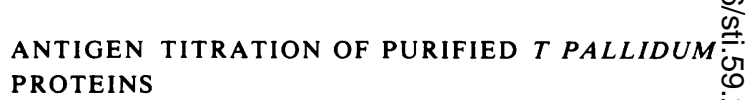

To determine the sensitivity of the ELISA using geleluted treponemal proteins preparations of $\mathrm{N}$ previously characterised proteins P1, P2P3, and 음 P4P5P6 ${ }^{1-4}$ were attached to wells of microtitre plates and used as probes for antibody reactivity. Antigen $\frac{\overrightarrow{ }}{0}$ titration was performed using pre-bled normal rabbit serum (NRS) and rabbit syphilitic serum (RSS) $\vec{\oplus}$ obtained at day 48 post-inoculation from $T$ pallidum- $\underset{\omega}{\infty}$ challenged animals. ${ }^{23}$ When diluted 1/100 RSS $_{\square}^{\circ}$ detected as little as $0.1 \mu \mathrm{g} / \mathrm{ml}$ of antigens P2P3 and P4P5P6 (fig 1). At the same serum dilution NRS produced only a minimal background response to all antigens regardless of concentration. Nevertheless $\frac{\circ}{\varnothing}$ $1.0 \mu \mathrm{g} / \mathrm{ml}$ was routinely used to allow a response $\stackrel{\varrho}{\rightarrow}$ which was $95 \%$ of the maximum ELISA reactivity $\overrightarrow{\vec{O}}$ detected with RSS to P2P3. This concentration additionally resulted in a value at least 30 times greater than that of NRS. Although RSS reacted with

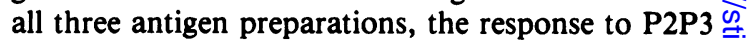
at $1.0 \mu \mathrm{g} / \mathrm{ml}$ was about 18 times greater than that to $\mathrm{P} 1$ and three to four times the response to P4P5P6. These data confirm that the predominant $\operatorname{IgG} \stackrel{\rho}{\circ}$ response by day 48 RSS is directed against P2P3 antigens as was previously shown by radioimmuno- $\frac{\mathrm{f}}{\mathrm{T}}$ precipitation and gel electrophoresis, ${ }^{3}$ (fig 2 ).

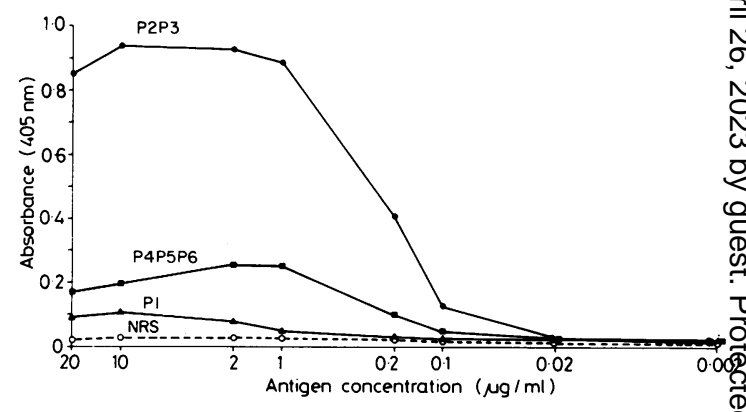

FIG 1 Comparative sensitivity of purified treponemal protein preparations by ELISA. Standard deviations were $<0.05$ for all values shown. 

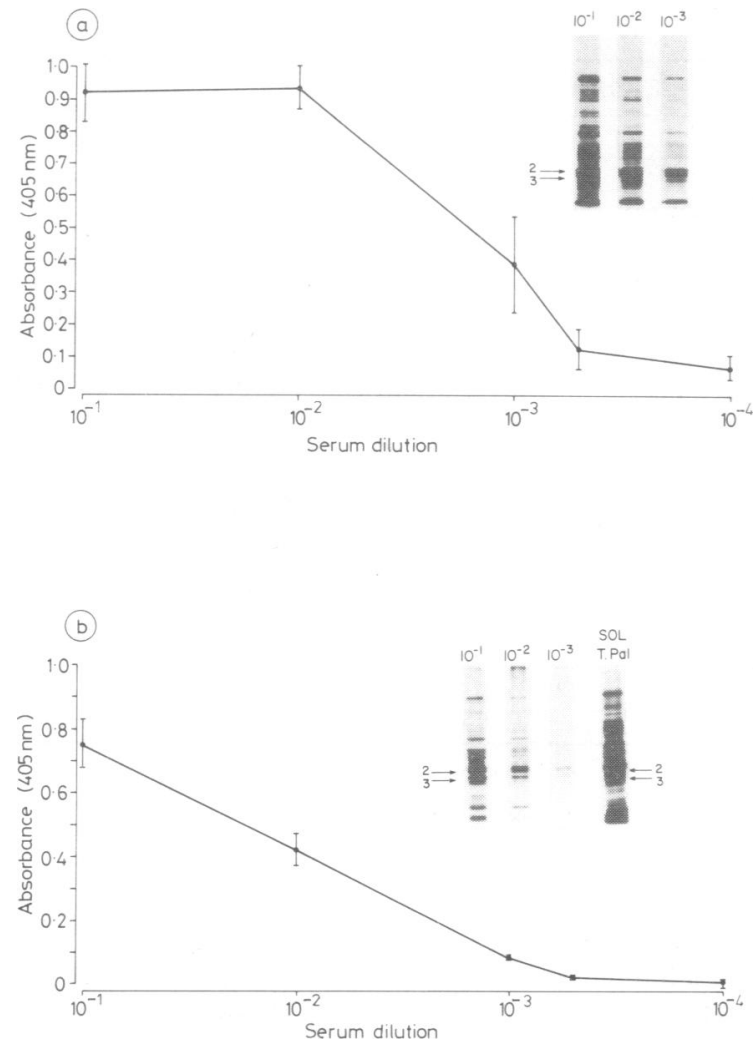

FIG 2 Titration of representative syphilitic rabbit serum IgG reactive against purified $P 2 P 3$ at day 48 (a) and dav 160 (b) after $T$ pallidum infection. Corresponding radioimmunoprecipitation fluorograms of $\left[{ }^{35} S\right]$ methioninelabelled, detergent-solubilised treponemal proteins reactive with the same serum are shown in the top right corner. The SOL T Pal profile (b) represents the profile of total treponemal proteins. Proteins previously characterised as P2P3 are denoted by arrows.
ANTIBODY TITRATION OF RSS TO PURIFIED P2P3 The kinetics of the IgG response of rabbits infected with $T$ pallidum was examined to determine antibody sensitivity of the ELISA to P2P3 at 10, 48, and 216 days after challenge. Antibodies against P2P3 antigens were detectable at each stage of infection (table I). To establish a consistent method for determining serum titration endpoints values greater than $20 \%$ of NRS were routinely considered positive. Of special interest was the high sensitivity of the assay. All test sera were positive except for the $1 / 10000$ dilution of sera at day 216 .

\section{SENSITIVITY OF THE ELISA COMPARED WITH RADIOIMMUNOPRECIPITATION}

Radioimmunoprecipitation used in combination with gel electrophoresis-fluorography is a highly accurate technique for detecting IgG against $T$ pallidum proteins. ${ }^{2-4}$ It was important, therefore, to compare the ELISA with RIP using RSS obtained at varying times after infection. These sera have been previously characterised for reactivity to specific treponemal proteins. $^{3}$

The ELISA detected a pronounced IgG response to P2P3 (50 ng protein/well) even at the $1 / 1000\left(10^{-3}\right)$ dilution of serum obtained on day 10 after challenge (table I). These data are consistent with previous observations of serum IgG antibody directed predominantly against P2P3 early in infected animals. ${ }^{2} 3$ At day 48 after inoculation serum diluted to $10^{-4}$ still showed detectable antibody against P2P3 (fig 2a). Corresponding RIP data indicated the presence of IgG to P2P3 up to the $10^{-3}$ dilution.

$A$ direct correlation between the ELISA and RIP is shown in fig $2 \mathrm{~b}$. Based on the RIP profile RSS at day 160 was primarily reactive to proteins $\mathrm{P} 2 \mathrm{P} 3$ at a serum dilution of $10^{-2}$ and to $\mathrm{P} 2$ with serum diluted $10^{-3}$. Similarly, the ELISA measured significant reactivity against $\mathrm{P} 2 \mathrm{P} 3$ at the $10^{-1}, 10^{-2}$, and $10^{-3}$ dilutions of RSS. Only low level absorbance was

TABLE I Antibody titration to purified P2P3 $T$ pallidum proteins

\begin{tabular}{|c|c|c|c|}
\hline \multirow[b]{2}{*}{ Serum dilution } & \multicolumn{3}{|c|}{ Absorbance (405nm) (days after inoculation): } \\
\hline & $\begin{array}{l}10 \\
(m e a n \pm S D)^{*}\end{array}$ & $\begin{array}{l}48 \\
(m e a n \pm S D)^{*}\end{array}$ & $\begin{array}{l}216 \\
(\text { mean } \pm S D)^{*}\end{array}$ \\
\hline $\begin{array}{l}1 / 10 \\
1 / 100 \\
1 / 500 \\
1 / 1000 \\
1 / 5000 \\
1 / 10000\end{array}$ & $\begin{array}{l}0.830 \pm 0 \\
0.598 \pm 0.005 \\
0.247 \pm 0.011 \\
0.153 \pm 0.003 \\
0.024 \pm 0.001 \\
0.011 \pm 0\end{array}$ & $\begin{array}{l}0.909 \pm 0.021 \\
0.763 \pm 0.023 \\
0.712 \pm 0.008 \\
0.336 \pm 0.011 \\
0.039 \pm 0.004 \\
0.019 \pm 0.001\end{array}$ & $\begin{array}{l}0.508 \pm 0.028 \\
0.254 \pm 0.018 \\
0.093 \pm 0.001 \\
0.047 \pm 0.008 \\
0.008 \pm 0.003 \\
0.001 \pm 0\end{array}$ \\
\hline
\end{tabular}

* Of duplicate samples from three different experiments. NRS at a 1/100 dilution gave values of $0 \cdot 020 \pm 0$. At further dilutions no NRS response was detectable $(<0 \cdot 001)$. 
TABLE II Comparative reactivity of rabbit sera IgG to whole $T$ pallidum and specific $P 2 P 3$ protein preparations

\begin{tabular}{|c|c|c|c|c|c|}
\hline \multirow[b]{2}{*}{ Experiment } & \multirow[b]{2}{*}{ Antigen } & \multirow[b]{2}{*}{ Serum dilution } & \multicolumn{3}{|c|}{ Absorbance (405nm) (days after inoculation): } \\
\hline & & & $\begin{array}{l}16 \\
\text { mean } \pm S D)^{*}\end{array}$ & $\begin{array}{l}64 \\
(m e a n \pm S D)^{*}\end{array}$ & $\begin{array}{l}160 \\
(\text { mean } \pm S D)^{*}\end{array}$ \\
\hline \multirow[t]{2}{*}{1} & P2P3 preparation & $\begin{array}{l}1 / 10 \\
1 / 100 \\
1 / 1000 \\
1 / 5000 \\
1 / 10000\end{array}$ & $\begin{array}{l}0.864 \pm 0.003 \\
0.756 \pm 0.021 \\
0.288 \pm 0.006 \\
0.063 \pm 0.002 \\
0.030 \pm 0.009\end{array}$ & $\begin{array}{l}0.856 \pm 0.044 \\
0.959 \pm 0.081 \\
0.513 \pm 0.007 \\
0.178 \pm 0.002 \\
0.103 \pm 0.008\end{array}$ & $\begin{array}{l}0.809 \pm 0.030 \\
0.460 \pm 0.028 \\
0.091 \pm 0.005 \\
0.020 \pm 0.003 \\
0.014 \pm 0.004\end{array}$ \\
\hline & Whole $T$ pallidum & $\begin{array}{l}1 / 10 \\
1 / 100 \\
1 / 1000 \\
1 / 5000 \\
1 / 10000\end{array}$ & $\begin{array}{l}0.519 \pm 0.016 \\
0.246 \pm 0.007 \\
0.088 \pm 0.008 \\
0.042 \pm 0.015 \\
0.037 \pm 0.022\end{array}$ & $\begin{array}{l}0.614 \pm 0.110 \\
0.347 \pm 0.040 \\
0.138 \pm 0.028 \\
0.105 \pm 0.024 \\
0.068 \pm 0.008\end{array}$ & $\begin{array}{l}0.623 \pm 0.213 \\
0.584 \pm 0.060 \\
0.136 \pm 0.084 \\
0.051 \pm 0.012 \\
0.009 \pm 0.013\end{array}$ \\
\hline \multirow[t]{2}{*}{2} & P2P3 preparation & $\begin{array}{l}1 / 10 \\
1 / 100 \\
1 / 1000 \\
1 / 5000 \\
1 / 10000\end{array}$ & $\begin{array}{l}0.950 \pm 0.015 \\
0.827 \pm 0.128 \\
0.224 \pm 0.006 \\
0.051 \pm 0.006 \\
0.026 \pm 0.003\end{array}$ & $\begin{array}{l}0.986 \pm 0.094 \\
0.908 \pm 0.068 \\
0.258 \pm 0.030 \\
0.068 \pm 0.006 \\
0.037 \pm 0\end{array}$ & $\begin{array}{l}0.695 \pm 0.053 \\
0.380 \pm 0.024 \\
0.077 \pm 0.006 \\
0.020 \pm 0.002 \\
0.013 \pm 0.005\end{array}$ \\
\hline & Whole $T$ pallidum & $\begin{array}{l}1 / 10 \\
1 / 100 \\
1 / 1000 \\
1 / 5000 \\
1 / 10000\end{array}$ & $\begin{array}{l}0.907 \pm 0 \\
0.883 \pm 0.141 \\
0.365 \pm 0.05 \\
0.076 \pm 0.006 \\
0.025 \pm 0.011\end{array}$ & $\begin{array}{l}0.788 \pm 0.028 \\
0.827 \pm 0.013 \\
0.246 \pm 0.06 \\
0.025 \pm 0.021 \\
0.018 \pm 0\end{array}$ & $\begin{array}{l}0.643 \pm 0.040 \\
0.352 \pm 0.139 \\
0.076 \pm 0.011 \\
0.026 \pm 0.036 \\
0.013 \pm 0.001\end{array}$ \\
\hline
\end{tabular}

* Of duplicate samples from three different experiments

detectable with NRS throughout these ELISA experiments indicating the absence of reactive antibody.

\section{COMPARISON OF ELISA SENSITIVITY WITH \\ P2P3 VERSUS WHOLE T PALLIDUM}

Because whole organisms have been used as sources of antigen for treponemal serodiagnostic assays ${ }^{13} 14$ it was of interest to compare ELISA titres of RSS between intact $T$ pallidum and P2P3 protein preparations. Representative test samples of RSS at days 16, 64, and 160 after infection were examined. As shown in table II antitreponemal IgG reactivity was more readily detected using purified P2P3 than whole $T$ pallidum. Additionally, decreased variability was shown using P2P3. In repeated experiments serum titrations based on P2P3 reactivity were consistently equal to or greater than whole treponemal organisms.

\section{Discussion}

In the present study an ELISA was developed for the analysis of serum IgG against immunogenic and biologically important Treponema pallidum proteins. Recent immunochemical dissection of virulent $T$ pallidum has established that certain treponemal proteins play key roles during the ontogeny of the host immune response to infection..$^{2-4}$ Radioimmunoassay-gel electrophoresis techniques, together with surface iodination procedures, show that outer membrane proteins P1 to P6 have high immunogenicity in experimentally infected rabbits and humans with syphilis. ${ }^{2-4}$ Proteins P1, P2, and P3 have also been implicated as putative receptorbinding proteins in the attachment of $T$ pallidum to host cell surfaces. ${ }^{2-4}$ Acrylamide gel purification and elution of these treponemal proteins has provided selective antigenic probes for the serological diagnosis of treponemal infection. Sensitivity of this microassay was confirmed by detection of specific binding of serum IgG to as little as $5 \mathrm{ng}$ per well of purified antigen (fig 1). Each preparative electrophoresis-protein elution experiment required the harvesting of $T$ pallidum from 6 to 8 rabbits. Approximately 100 to $200 \mu \mathrm{g}$ of specific treponemal 0 protein could be obtained providing sufficient antigen to coat a minimum of 20 microtitre plates or 2000 wells. Reproducible results were obtained using antigen-coated plates stored over a period of several months.

The sensitivity of the ELISA was equivalent to or $\mathbb{\omega}$ better than the RIP, avoiding the need to use $O$ radioactive reagents and time-consuming procedures. In addition, the use of purified treponemal proteins afforded a clear advantage to whole $T$ pallidum organisms since identification of specific antigenantibody complexes and high reproducibility of data were possible. The technical problems of treponemal clumping, masking of $T$ pallidum antigens with host components, ${ }^{1}$ and biological variations in treponemal populations ${ }^{1}$ were avoided. 
The ELISA has been successfully used for analysis of a wide variety of bacterial, viral, and cellular antigens. ${ }^{15-18}$ It is an efficient, simple, and relatively inexpensive assay, which is superior to other serological tests when highly immunogenic and purified antigenic indicators are used. Stability and long-term storage of reagents allow the assay to be particularly suitable for large-scale screening. As reported here, the technique resulted in a high degree of specificity and sensitivity. The rationale for selecting appropriate $T$ pallidum immunogens such as $\mathrm{P} 2 \mathrm{P} 3$ was a direct result of recent biochemical and immunological data. ${ }^{1-4}$ Characterisation of the kinetics of the humoral response to $T$ pallidum infection indicates that antibody against proteins P2P3 may correlate with the development of host immunity. In addition, detection of antibodies to these proteins in human syphilis ${ }^{34}$ and yaws ${ }^{4}$ further extends the application and relevance of this immunodiagnostic microassay.

\section{References}

1. Alderete JF, Baseman JB. Surface-associated host proteins on virulent Treponema pallidum. Infect Immun 1979; 26:1048-56.

2. Alderete JF, Baseman JB. Surface characterization of virulent Treponema pallidum. Infect Immun 1980; 30:814-23.

3. Alderete, JF, Baseman JB. Analysis of serum IgG against Treponema pallidum protein antigens in experimentally infected rabbits. Br J Vener Dis 1981;57:302-8.

4. Baseman JB, Hayes EC. Molecular characterization of receptor binding proteins and immunogens of virulent Treponema pallidum. J Exp Med 1980; 151:573-86.

5. LeClair RA, Montague TS, Keetin LM. Biologic false-positive reactions for syphilis as measured by the Treponema pallidum immobilization test. $J$ Med 1972; 3:264-9.
6. Garner MF, Backhouse JL. Chronic biological false-positive reactions to serological test for syphilis in blood donors. J Clin Pathol 1970; 23:478-80.

7. Luger A, Schmidt BL, Spendlingwimmer I, Steyrer K. Specificity of the Treponema pallidum haemagglutination test. Br J Vener Dis 1981;57:178-80.

8. Pien FD, Markowitz $\mathrm{H}$, McKenna $\mathrm{CH}$, Schroeter AL. Problems with beaded fluorescence pattern in FTA-ABS test. J Am Vener Dis Assoc 1976; 3:20-4.

9. Rathlev T. Haemagglutination test utilizing pathogenic Treponema pallidum for the serodiagnosis of syphilis. $\mathrm{Br} J$ Vener Dis 1967; 43:181-5.

10. Nell EE, Hardy PH. The use of freeze-preserved treponemes in the Treponema pallidum immunobilization test. Crvobiology 1972;9:404-10.

11. Roehrig JT, Corser JA, Schlesinger MJ. Isolation and characterization of hybrid cell lines producing monoclonal antibodies directed against the structural proteins of Sinbis virus. Virology 1980; 101;41-9.

12. Bradford M. A rapid and sensitive method for the quantitation of microgram quantities of protein utilizing the principles of protein-dye binding. Anal Biochem 1976; 72:248-54.

13. Zeltzer PM, Pepose JS, Bishop NH, Miller JN. Microassay for immunoglobulin $G$ antibodies to Treponema pallidum with radioiodinated protein A from Staphylococcus aureus: Immunoglobulin $G$ response in experimental syphilis in rabbits. Infect Immun 1978;21:163-70.

14. Pepose JS, Bishop NH, Feigenbaum S, Miller JN, Zeltzer PM The humoral immune response in rabbits infected with Treponema pallidum: comparison of antibody levels measured by the staphylococcal protein A-IgG (SPA-TP) microassay with VDRL, FTA-Abs, and TPI antibody responses during the development of acquired resistance to challenge. Sex Transm Dis 1980; 7: 125-9

15. Voller A, Bidwell D, Bartlett A. Microplate enzyme immunoassays for the immunodiagnosis of virus infections. In: Rose NR, Friedman H, eds. Manual of Clinical Immunology. Washington, DC: American Society for Microbiology, 1976; 506-12.

16. Cobbold SP, Waldmann H. A rapid solid-phase enzyme-linked binding assay for screening monoclonal antibodies to cell surface antigens. J Immunol Method 1981; 44:125-33.

17. Douillard JY, Hoffman T, Heberman RB. Enzyme-linked immunosorbent assay for screening monoclonal antibody production: use of intact cells as antigen. J Immunol Method 1980; 39: 309-16.

18. Horowitz SA, Cassell GH. Detection of antibodies to Mycoplasma pulmonis by an enzyme-linked immunosorbent assay. Infect Immun 1978; 22: 161-70. 